\title{
PENGEMBANGAN BAHAN AJAR SUHU DAN KALOR BERBASIS AUTOPLAY MEDIA STUDIO UNTUK MENINGKATKAN HASIL BELAJAR SISWA
}

\author{
Meidy Atina Kuron'1), Rasilemba Welua') \\ 1)Program Studi Teknik Informatika, Universitas Sariputra Indonesia Tomohon, Manado, Sulawesi Utara, Indonesia
}

Corresponding author : Meidy Atina Kuron

E-mail : meidykuron@unsrittomohon.ac.id

Diterima 09 Agustus 2021, Direvisi 24 Agustus 2021, Disetujui 27 Agustus 2021

\begin{abstract}
ABSTRAK
Pengembangan Bahan Ajar Suhu dan Kalor berbasis Autoplay media studio ini bertujuan untuk menghasilkan produk bahan ajar fisika berbasis Autoplay media studio untuk meningkatkan hasil belajar siswa dengan memperbaiki proses pembelajaran menjadi lebih mudah dan menarik. Penelitian ini dilakukan di SMA Negeri 1 Tondano dengan menggambil materi suhu dan kalor di kelas X IPA 2 dengan jumlah siswa 28 orang pada semester ganjil tahun ajaran 2019-2020. Penelitian ini menggunakan metode Research and Delevopment (R\&D) dengan four-D-models yang dikembangkan oleh Thiagarajan, Semmel and Semmel. Model ini terbagi atas 4 tahap yaitu Define (pendefinisian), design (perancangan), develop (pengembangan) dan disseminate (penyebaran). Bahan ajar yang dikembangkan telah melewati proses pengujian oleh para ahli serta diujicobakan pada siswa dalam kelompok kecil untuk memperoleh respon siswa dan selanjutnya diujicobakan pada kelompok besar atau real class dan dianalisis hasil belajarnya. Hasil penelitian menunjukan bahan ajar yang dikembangkan memiliki persentase rata-rata sebesar $88 \%$ dari hasil validasi oleh ahli materi, $97 \%$ dari hasil validasi oleh ahli media dan termasuk dalam kategori sangat kuat. Respon siswa terhadap bahan ajar berbasis Autoplay Media Studio pada uji kelompok kecil memberikan respon sebesar 96,3\% termasuk dalam kategori sangat kuat. Eksperimen yang digunakan adalah metode desain by subject dimana sampel diberi perlakuan berbeda dalam dua periode. Periode pertama siswa diajar dengan model konvensional menggunakan media yang biasa digunakan di kelas dan periode kedua siswa diajar menggunakan Autoplay media studio yang dikembangkan dalam penelitian ini. Sebagai prasyarat pengujian normalitas diperoleh nilai signifikan pada periode 1 adalah 0.297 dan periode 2 diperoleh 0.256 lebih besar dari taraf nyata 0.05 maka dapat disimpulkan kedua data pada periode 1 dan periode 2 berdistribusi normal. Hasil pengujian hipotesis dibantu dengan aplikasi SPSS nilai $\left|t_{\text {hitung }}>t_{\text {tabel }}\right|$ atau $\mid 19.483>2.473$ | dan berdasarkan signifikansi $<0.05$ maka $\mathrm{H}_{0}$ ditolak dan disimpulkan bahwa ratarata hasil belajar siswa yang diajar dengan menggunakan bahan ajar fisika berbasis Autoplay media studio lebih tinggi daripada hasil belajar siswa yang diajar dengan model kovensional.
\end{abstract}

Kata kunci: Pengembangan; Bahan Ajar; Multimedia.

\begin{abstract}
The development of Autoplay Media Studio-based Temperature and Heat Teaching Materials aims to produce Autoplay media studio-based physics teaching materials to improve student learning outcomes by making the learning process easier and more interesting. This research was conducted at SMA Negeri 1 Tondano by taking temperature and heat material in class X IPA 2 with 28 students in the odd semester of the 2019-2020 school year. This study uses the Research and Development (R\&D) method with four-D-models developed by Thiagarajan, Semmel and Semmel. This model is divided into 4 stages, namely Define, design, develop and disseminate. The teaching materials developed have passed the testing process by experts and were tested on students in small groups to obtain student responses and then tested in large groups or real classes and analyzed the learning outcomes. The results showed that the teaching materials developed had an average percentage of $88 \%$ of material expert validation results, $97 \%$ of media expert validation results and included in the very strong category. Student responses to teaching materials based on Autoplay Media Studio in the small group test gave a response of $96.3 \%$ which was included in the very strong category. The experimental method used is the design by subject method where the sample is given different treatment in two periods. In the first period students were taught using a conventional model using media commonly used in the classroom and in the second period students were taught using the Autoplay media studio developed in this study. As a prerequisite for normality testing, the significant value obtained in period 1 is 0.297 and period 2 is 0.256 which is greater than the significance level of 0.05 , so it can be concluded that both data in period 1 and period 2 are normally distributed. The results of hypothesis testing are assisted by the application of SPSS 16.0
\end{abstract}


values |t hitung $>\mathrm{t}$ table| or $|19,483>2.473|$ and based on a significance $<0.05$ then $\mathrm{H}_{0}$ is rejected and it is concluded that the average learning outcomes of students who are taught using physics teaching materials based on autoplay media studio are higher than the learning outcomes of students who are taught using conventional models.

Keywords: Development; Teaching Materials; Multimedia.

\section{PENDAHULUAN}

Peristiwa yang terjadi di suatu negara dapat diketahui di negara lain pada saat dan detik itu juga tanpa terhalang oleh jarang dan waktu. Hal ini tentunya disebabkan oleh kemajuan teknologi yang dirasakan oleh banyak kalangan masyarakat termasuk di Indonesia dalam segala bidang. Hubungan komunikasi antarmanusia dapat dilakukan melalui berbagai alat komunikasi seperti handphone, radio, televisi, film dan sebagainya tetapi juga melalui media sosial yang memanfaatkan internet seperti facebook, twitter email, chating, path dan sebagainya telah mempermudah adanya sosialisasi dan komunikasi jarak jauh yang banyak dimanfaatkan masyarakat termasuk peserta didik.

Penggunaan multimedia pembelajaran pada era kemajuan teknologi saat ini tentunya sudah tidak asing lagi termasuk di bidang pendidikan. Beberapa sekolah di pusat perkotaan telah dilengkapi dengan sistem multimedia untuk menunjang pembelajaran dan telah terjangkau jaringan internet. Pemanfaatan Multimedia dalam pembelajaran memiliki banyak manfaat diantaranya sebagai media pembelajaran, desain, arsitektur, games, dunia medis, film, olahraga, iklan/promosi dan lainlain (Ariani \& Haryanto, 2010)

Proses pembelajaran yang terselenggara dengan baik menuntut adanya komunikasi yang baik pula. Menurut (Arsyad, 2012) "salah satu yang menentukan capaian hasil belajar siswa adalah kemampuan pendidik dalam mengkomunikasikan dan menerapkan bahan ajar agar dapat dipahami dan dimengerti dengan baik oleh siswa". Kendala yang terjadi dalam kegiatan pembelajaran seringkali disebabkan karena keterbatasan guru dalam menyampaikan bahan ajar serta kemampuan siswa yang berbeda-beda saat menyerap materi (Daryanto, 2010). Mengingat ilmu pengetahuan begitu luas, kompleks dan mendalam, seorang guru memiliki kemampuan yang terbatas dalam mengkomunikasikan informasi dan pengetahuan apalagi bertambahnya kesulitan belajar siswa ketika diperhadapkan dengan materi ajar yang memuat konsep, konteks dan matematis yang serius seperti dalam bidang studi fisika. Demikian pun kesulitan terdapat pada keterbatasan waktu dan kemampuan indra seorang guru untuk menjelaskan kompetensi dan tujuan pembelajaran fisika yang harus dicapai dalam setiap pertemuan sehingga sulit untuk dicapai secara maksimal.

Berdasarkan observasi awal yang telah dilakukan di SMA Negeri 1 Tondano sebagai objek penelitian, khususnya pada kelas $X$ didapati pencapaian prestasi belajar pada semester ganjil tahun ajaran 2018-2019 ratarata skor belajar hanya 60 - 65 dan belum mencapai hasil yang diharapkan. Metode serta media pembelajaran konvensional masih mendominasi proses pembelajaran dan membuat pembelajaran berlangsung monoton sehingga menjadi salah satu alasan siswa kurang termotivasi dengan pembelajaran fisika. Pemanfaatan teknologi dibidang pendidikan dalam proses pembelajaran dipandang baik untuk mengatasi permasalahan keterbatasan media mengingat berbagai manfaat serta kemudahan yang dapat diperoleh melalui penggunaan multimedia. Menurut (Fitria, 2013) "teknologi pendidikan bisa dipahami sebagai sesuatu proses yang kompleks dan terpadu termasuk prosedur ide dan peralatan untuk menganalisis masalah, mencari jalan untuk mengatasi permasalahan, melaksanakan, menilai, dan mengelola pemecahan masalah yang mencakup semua aspek belajar manusia".

Mengingat perkembangan teknologi multimedia yang semakin pesat menjadi salah satu kesempatan bagi dunia pendidikan untuk membuka peluang-peluang yang lebih besar sebagai sarana untuk melengkapi dan menunjang proses belajar mengajar di sekolah sebab kelemahan dan keterbatasan kemampuan manusia dapat ditutupi dan ditopang oleh teknologi agar segala aktivitas (actus, action) manusia menjadi lebih mudah, cepat dan maksimal (Haryanto, 2010).

Berbagai kemudahan dalam hal pemanfaatan teknologi menuntut dan memaksa manusia terus bergerak maju dalam inovasi dan kreatifitas seakan mengisyaratkan bahwa bagi yang mampu menyesuaikan diri dengan perkembangan dialah yang akan bertahan dan berkembang maju tetapi bagi yang tidak mampu menyesuaikan diri maka akan ketinggalan dan mundur. Dalam hal guru sebagai tenaga pendidik tentunya menjadi salah satu sumber daya manusia yang harus 
mampu menyesuaikan dengan kemampuan intelektual dan kreativitasnya memikirkan dan mengupayakan proses pendidikan yang lebih optimal dengan berbagai pendekatan, model, metode serta media pembelajaran berbasis teknologi. Penggunaan multimedia memanfaatkan berbagai software diantaranya microsoft power point, macromedia flash, $i$ spring dan Autoplay media studio untuk membuat berbagai animasi, video, gambar, suara, dan lain sebagainya. Beberapa pengembangan bahan ajar menggunakan Autoplay media studio telah dirancang dan dibuat sebelumnya namun tidak dapat menampilkan kuis essay dan objektif sebab tidak mengkombinasikan pada software $i$-spring dan sejenisnya.

Dalam penelitian ini, ketiga software yaitu Autoplay media studio, $i$-spring dan power point digunakan dalam pembuatan bahan ajar fisika kelas $\mathrm{X}$ materi suhu dan kalor termasuk perpindahan kalor. Software $i$-spring digunakan untuk membuat kuis dan latihan soal, software power point untuk membuat animasi dan simulasi serta materi suhu dan kalor. Software Autoplay media studio berfungsi untuk mengkombinasikan software i-Spring dan power point menjadi satu bahan ajar yang lengkap dan menarik. Pengembangan bahan ajar melalui softwere Autoplay media studio dapat membantu proses pembelajaran antara lain penggunaan waktu lebih efisien selama pembelajaran berlangsung, membantu kompetensi guru dalam mencapai tujuan pembelajaran serta memperbaiki penggunaan metode belajar menjadi lebih efektif. Berdasarkan uraian di atas, maka dipandang perlu untuk melakukan penelitian pengembangan bahan ajar suhu dan kalor berbasis Autoplay media studio untuk meningkatkan hasil belajar siswa.

\section{METODE PENELITIAN}

Penelitian ini dilakukan di SMA Negeri 1 Tondano pada semester ganjil tahun pelajaran 2019-2020 dengan subjek penelitian siswa kelas $X$ yang berjumlah 28 Siswa. Dalam prosedur penelitian pengembangan bahan ajar berbasis softwere multimedia ini penulis menggunakan metode penelitian dan pengembangan atau "Research and Development (R \& D)" mengikuti tahap-tahap penelitian pengembangan four-D-models (model 4D) menurut Thiagarajan, Semmel and Semmel (Pressman, R.S., 1997., Prasetyo, 2012. dalam Palilingan, R. 2014). "Model 4-D terdiri atas 4 tahap pengembangan yaitu Define (pendefinisian atau pelacakan), design (perancangan), develop (pengembangan) dan disseminate (pendiseminasian atau penyebaran)". Dalam penelitian ini bagian eksperiment dengan pengujian empiris digunakan variabel bebas pada periode pertama yaitu model pembelajaran konvensional dengan media konvensional dan periode kedua variabel bebas model pembelajaran konvensional berbasis Autoplay media studio sedangkan variabel terikatnya adalah hasil belajar siswa pada periode pertama dan kedua.

Tahap pertama yaitu Define (pendefinisian atau pelacakan) merupakan tahap penjajakan yang meliputi pengkajian tentang permasalahan dan potensi yang terdapat di SMA Negeri 1 Tondano. Observasi dilakukan dengan pengamatan dan wawancara langsung dengan guru mata pelajaran fisika serta beberapa orang siswa. Pengkajian ini menghasilkan: 1) Masalah yang dihadapi sekolah antara lain guru belum memanfaatkan sarana multimedia yang tersedia di sekolah dalam pembelajaran di kelas sehingga suasana belajar mengajar bersifat teacher center, 2) Sarana dan prasarana yang menunjang pembelajaran di SMA Negeri 1 Tondano antara lain terdapat laboratorium komputer dan ruang khusus multimedia sehingga memungkinkan proses belajar mengajar menggunakan bahan ajar fisika berbasis Autoplay media studio, 3) Analisis siswa dan kebutuhan pengembangan bahan ajar dimana dalam penelitian Menggunakan bahan ajar fisika yang dirancang menggunakan Autoplay media studio untuk memperbaiki proses pembelajaran di sekolah, 4) Selanjutnya disusun kerangka penelitian yang meliputi bahan ajar yang inovatif berbasis multimedia (gambar, animasi dan simulasi flash, video dan isi materi) dengan mempertimbangkan penelitian-penelitian yang relevan dibidang pemanfaatan teknologi multimedia terhadap pembelajaran di sekolah yang terbukti bermanfaat untuk diterapkan dan dibangun.

Tahap kedua design (perancangan), merupakan tahap pembuatan/perancangan bahan ajar fisika suhu dan kalor berbasis Autoplay media studio. Pada tahap ini dibuat rancangan bahan ajar yang diawali dengan penyiapan alat dan bahan meliputi : 1) Software powerpoint, iSpring digabungkan dalam Autoplay media studio untuk pembuatan bahan ajar, 2) Isi bahan ajar meliputi materi suhu, kalor dan perpindahan kalor sesuai silabus di kelas $X$ SMA Negeri 1 Tondano semester ganjil TA. 2019-2020, 3) Persiapan instrumen dan kriteria untuk mengevaluasi design dan prototipe produk bahan ajar fisika berbasis software multimedia.

Tahap ketiga yaitu pengembangan (development) merupakan tahap perbaikan 
desain bahan ajar fisika berbasis software multimedia (perbaikan/ revisi 1) yang didasarkan oleh saran dan kritik reviewer dan hasil ujicoba produk multimedia. Ujicoba produk dilakukan dalam 2 bagian yaitu ujicoba untuk mengevaluasi bahan ajar berbasis software multimedia secara teoritis yang melibatkan reviewer ahli materi dan reviewer ahli media serta melibatkan siswa dalam kelompok kecil untuk melihat tanggapan dan respon siswa terhadap bahan ajar serta uji coba lapangan secara empiris dengan menggunakan metode kuasi eksperimen design by subject.

Evaluasi oleh ahli materi terhadap bahan ajar berbasis software multimedia ini bertujuan untuk memvalidasi bahan ajar oleh tim dosen ahli materi sebelum dilakukan uji lapangan. "Berdasarkan data yang diperoleh, dihitung besar presentasenya dengan cara membandingkan antara jumlah nilai yang dicapai dengan jumlah nilai maksimum dikalikan $100 \%$ " (Arikunto, 2010). Terdapat 15 butir indikator yang digunakan oleh ahli materi untuk mereview bahan ajar yaitu seperti berikut.

Tabel 1. Indikator review ahli materi terhadap bahan ajar

\section{INDIKATOR}

Materi bahan ajar sesuai dengan kaedah ilmu pengetahuan alam

\begin{tabular}{l} 
Materi bahan ajar mempunyai konsep yang benar \\
Bahan ajar memuat hal-hal baru \\
Materi dalam bahan ajar dikembangkan \\
berdasarkan fakta \\
\hline Materi bahan ajar relevan dengan tujuan \\
pembelajaran \\
\hline Materi ajar ada dalam kurikulum sekolah \\
\hline Materi disajikan dengan animasi pembelajaran \\
yang mudah dimengerti \\
\hline Bahan ajar mencantumkan judul sesuai dengan isi \\
materi \\
\hline Materi dalam bahan ajar bersifat deskriptif \\
\hline Bahan ajar mencantumkan standar kompetensi \\
dan kompetensi dasar yang harus dicapai \\
\hline Bahan ajar menggunakan bahasa baku yang \\
dimengerti \\
Latihan soal, simulasi dan uji kompetensi sesuai \\
dengan indikator yang dicapai \\
\hline Bahan ajar mencantumkan daftar rujukan yang \\
digunakan \\
\hline Isi materi dan contoh soal dalam bahan ajar dapat \\
menstimulus siswa mengembangkan pengetahuan \\
\hline Bahan ajar mencantumkan identitas penyusun \\
\hline ALTERNATIF PILIHAN dan SKOR \\
Sangat Baik (SB) = 5 \\
Baik (B) = 4 \\
Cukup Baik (CB) = 3 \\
Kurang Baik (KB) = 2 \\
Tidak Baik (TB) =1 \\
Format evaluasi diadaptasi dari (Setyosari, 2010)
\end{tabular}

Interpretasi skor : "Angka $0 \%-20 \%=$ Sangat lemah, Angka $21 \%$ - $40 \%$ = Lemah, Angka 41 $\%-60 \%=$ Cukup, Angka $61 \%-80 \%=$ Kuat, Angka $81 \%-100 \%$ = Sangat Kuat".

$$
\begin{aligned}
& \frac{\text { Jumlah skor yang dicapai }}{\text { jumlah skor maksimum }} \times 100 \%=\frac{66}{75} \times 100 \% \\
& =88 \%
\end{aligned}
$$

Berdasarkan perhitungan maka didapatkan angka $88 \%$ dan termasuk dalam kriteria sangat kuat dapat dilihat pada gambar dibawah ini.

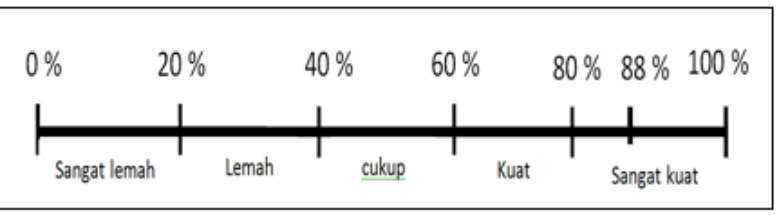

Gambar 1. Skala penilaian kontinum ahli materi terhadap bahan ajar berbasis multimedia.

Selanjutnya dilakukan evaluasi ahli media dengan tujuan memvalidasi bahan ajar sebelum dilakukan uji coba lapangan. Adapun terdapat 3 bagian utama indikator yang digunakan untuk mereview bahan ajar antara lain kelayakan tampilan, kelayakan penyajian dan Kelayakan pendukung yang masingmasing diuraikan sebagai berikut :

Tabel 2. Indikator review ahli media terhadap bahan ajar

\section{INDIKATOR}

\begin{tabular}{l}
\hline Kelayakan Tampilan \\
\hline Tampilan awal produk \\
\hline Teks jelas dan dapat dibaca \\
\hline Video/flash/animasi tidak terganggu \\
\hline Audio terdengar jelas \\
\hline Keterpaduan komposisi dan warna \\
\hline Fungsi sebagai media pembelajaran \\
\hline Alat bantu link/navigasi bekerja \\
\hline Kemudahan mengakses \\
\hline Kualitas tampilan gambar \\
\hline Daya tahan aktifitas mandiri dan kelompok \\
\hline Kelayakan Penyajian \\
\hline Sistematika penyajian \\
\hline Materi mudah dipahami \\
\hline Penyajian mudah diikuti \\
\hline Video memudahkan pemahaman materi \\
\hline Kemudahan memahami konsep \\
\hline Kemudahan memahami contoh / latihan soal \\
\hline Kelayakan Pendukung \\
\hline Tersedia program pendukung untuk diinstal \\
\hline Kemudahan dalam menginstal program \\
\hline Dapat dijalankan di komputer lain \\
\hline Kecepatan respon program \\
\hline ALTERNATIF PILIHAN dan SKOR \\
Sangat Baik (SB) = 5 \\
Baik (B) = 4 \\
Cukup Baik (C) = 3 \\
\hline
\end{tabular}


Kurang Baik $(\mathrm{KB})=2$

Tidak Baik $(\mathrm{TB})=1$

$\frac{\text { Jumlah skor yang dicapai }}{\text { jumlah skor maksimum }} \times 100 \%=\frac{65}{100} \times 100 \%$ $=65 \%$

Hasil perhitungan maka didapatkan angka 65\% dan termasuk dalam kriteria kuat namun bahan ajar berbasis software multimedia harus disempurnakan lagi untuk mendapatkan hasil yang lebih maksimal.

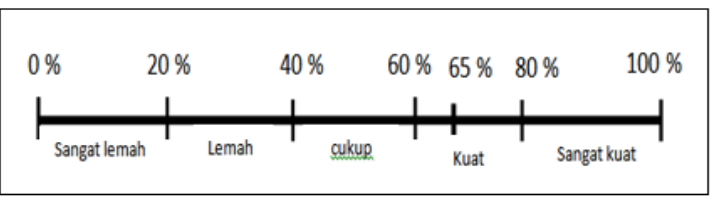

Gambar 2. Skala penilaian kontinum ahli media terhadap bahan ajar berbasis multimedia.

Reviewer telah memberikan tanggapan dan saran untuk perbaikan bahan ajar selanjutnya yang dapat dilihat pada tabel berikut ini.

Tabel 3. Saran ahli media terhadap bahan ajar

\begin{tabular}{|c|c|c|}
\hline Indikator & $\begin{array}{c}\text { Respon / } \\
\text { Tanggapan }\end{array}$ & Saran \\
\hline $\begin{array}{l}\text { Tampilan } \\
\text { awal } \\
\text { produk }\end{array}$ & $\begin{array}{l}\text { Terdapat } \\
\text { banyak ruang } \\
\text { kosong }\end{array}$ & $\begin{array}{l}\text { Beri animasi } \\
\text { tentang materi } \\
\text { atau kata } \\
\text { pembuka }\end{array}$ \\
\hline $\begin{array}{l}\text { Teks, } \\
\text { gambar, } \\
\text { video, flash } \\
\text { animasi }\end{array}$ & $\begin{array}{l}\text { Belum } \\
\text { dijelaskan } \\
\text { maksud } \\
\text { penampilan } \\
\text { video, gambar, } \\
\text { dan animasi }\end{array}$ & $\begin{array}{l}\text { Beri informasi } \\
\text { dari maksud } \\
\text { gambar dan } \\
\text { video yang } \\
\text { digunakan. }\end{array}$ \\
\hline Audio & $\begin{array}{l}\text { Suara } \\
\text { terdengar } \\
\text { tumpang tindih }\end{array}$ & $\begin{array}{l}\text { Beri tombol } \\
\text { navigasi untuk } \\
\text { menyalakan dan } \\
\text { mematikan } \\
\text { audio }\end{array}$ \\
\hline $\begin{array}{l}\text { Daya } \\
\text { dukung }\end{array}$ & $\begin{array}{l}\text { Tidak } \\
\text { disediakan } \\
\text { aplikasi } \\
\text { pendukung }\end{array}$ & $\begin{array}{l}\text { Sediakan } \\
\text { program yang } \\
\text { harus diinstal } \\
\text { untuk } \\
\text { menjalankan } \\
\text { bahan ajar }\end{array}$ \\
\hline $\begin{array}{l}\text { Contoh } \\
\text { soal dan } \\
\text { Latihan } \\
\text { soal }\end{array}$ & $\begin{array}{l}\text { Tidak } \\
\text { menampilkan } \\
\text { input dan } \\
\text { output }\end{array}$ & $\begin{array}{l}\text { Tampilkan flash } \\
\text { input output }\end{array}$ \\
\hline
\end{tabular}

Sumber: Format diadaptasi dari (Putra, N. 2011)

Berdasarkan tanggapan dan saran yang dikemukakan oleh reviewer disimpulkan bahwa bahan ajar yang sedang dikembangkan, desainnya masih perlu direvisi sebelum diujicobakan di lapangan. Setelah dilakukan revisi pada produk bahan ajar telah mendapatkan tanggapan yang baik oleh reviewer dengan hasil revisi $97 \%$ yang dihitung besar presentasenya dengan cara "membandingkan antara jumlah nilai yang dicapai dengan jumlah nilai maksimum dikalikan 100 \%" (Arikunto, 2010). Interpretasi skor :

$$
\begin{gathered}
\frac{\text { Jumlah skor yang dicapai }}{\text { jumlah skor maksimum }} \times 100 \%=\frac{97}{100} \times 100 \% \\
=97 \%
\end{gathered}
$$

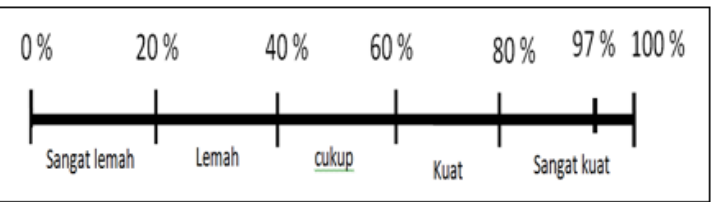

Gambar 3. Skala penilaian kontinum ahli media terhadap bahan ajar berbasis multimedia bagian revisi

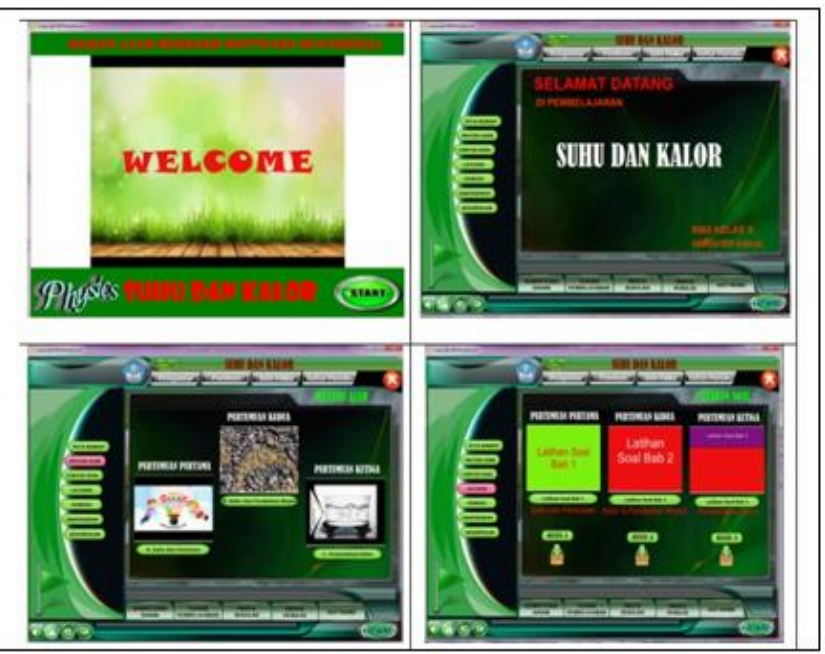

Gambar 4. Tampilan bahan akar Suhu dan Kalor

\section{Ujicoba Kelompok Kecil}

Tahap selanjutnya dilakukan ujicoba kelompok kecil yaitu kelompok siswa yang terdiri atas 7 orang siswa kelas X IPA SMA Negeri 1 Tondano yang tersebar secara acak di 7 kelas IPA sesuai prestasi akademik. Adapun Indikator yang digunakan dalam ujicoba kelompok kecil ini terdiri atas 10 indikator yang dibagi dalam 2 kriteria utama yaitu kriteria materi pembelajaran dan kriteria media pembelajaran seperti tabel dibawah ini.

\begin{tabular}{|c|c|c|c|c|c|c|c|}
\hline \multirow{3}{*}{ No } & \multirow{3}{*}{$\begin{array}{l}\text { INDIKATOR } \\
\text { PENILAIAN }\end{array}$} & \multicolumn{6}{|c|}{ Alternatif Pilihan } \\
\hline & & $\begin{array}{l}\text { S } \\
\mathbf{B}\end{array}$ & B & $\begin{array}{l}\text { C } \\
\text { B }\end{array}$ & $\begin{array}{l}\mathbf{K} \\
\mathbf{B}\end{array}$ & $\begin{array}{l}\mathbf{T} \\
\mathbf{B}\end{array}$ & $\begin{array}{c}\text { Pers } \\
\text { enta } \\
\text { se }\end{array}$ \\
\hline & & 5 & 4 & 3 & 2 & 1 & $(\%)$ \\
\hline & Kriteria Materi & & & & & & \\
\hline 1 & Isi materi sudah lengkap & 5 & 2 & - & - & - & $\begin{array}{c}94,3 \\
\%\end{array}$ \\
\hline 2 & $\begin{array}{l}\text { Materi disajikan dengan } \\
\text { animasi penunjang }\end{array}$ & 7 & - & - & - & - & $\begin{array}{c}100 \\
\%\end{array}$ \\
\hline
\end{tabular}

Tabel 4. Indikator penilaian uji kelompok kecil 


\begin{tabular}{|c|c|c|c|c|c|c|}
\hline 3 & $\begin{array}{lr}\text { Materi tersusun } & \text { dan } \\
\text { disajikan } & \text { secara } \\
\text { sistematika } & \end{array}$ & 3 & 4 & - & - & $\begin{array}{c}91,4 \\
\%\end{array}$ \\
\hline 4 & $\begin{array}{l}\text { Materi yang disajikan } \\
\text { sesuai dengan kurikulum } \\
\text { sekolah }\end{array}$ & 5 & 2 & - & - & $\begin{array}{c}94,3 \\
\%\end{array}$ \\
\hline 5 & $\begin{array}{l}\text { Isi materi dan contoh } \\
\text { soal dapat membantu } \\
\text { siswa memahami materi } \\
\text { yang diajarkan dan } \\
\text { menstimulus siswa } \\
\text { mengembangkan } \\
\text { pengetahuan }\end{array}$ & 6 & 1 & - & - & $\begin{array}{l}97,1 \\
4 \%\end{array}$ \\
\hline & Kriteria Media & & & & & \\
\hline 6 & Tampilan produk jelas & 7 & - & - & - & $\begin{array}{c}100 \\
\%\end{array}$ \\
\hline 7 & $\begin{array}{l}\text { Video/flash/animasi tidak } \\
\text { terganggu }\end{array}$ & 6 & 1 & - & - & $\begin{array}{l}97,1 \\
4 \% \\
\end{array}$ \\
\hline 8 & $\begin{array}{l}\text { Siswa mudah } \\
\text { mengoprasikan produk }\end{array}$ & 5 & 2 & - & - & $\begin{array}{c}94,3 \\
\%\end{array}$ \\
\hline 9 & Audio terdengar jelas & 7 & - & - & - & $\begin{array}{c}100 \\
\% \\
\end{array}$ \\
\hline 10 & $\begin{array}{l}\text { Keterpaduan komposisi } \\
\text { warna dan gambar }\end{array}$ & 5 & 2 & - & - & $\begin{array}{c}94,3 \\
\%\end{array}$ \\
\hline
\end{tabular}

Skor hasil :

Skor tertinggi 350

Skor terendah 70

Total skor capaian 285

Persentase skor :

$$
=\frac{337}{350} \times 100 \%=96,3 \%
$$

Berdasarkan data yang diperoleh dari tiap butir dalam or yang dihitung besar presentasenya dengan cara "membandingkan antara jumlah nilai yang dicapai dengan jumlah nilai maksimum dikalikan 100\%" diperoleh interpretasi skor capaian $\pm 90 \%-100 \%$. Sedangkan dari 10 indikator skor yang dicapai untuk kategori sangat baik (SB) sebesar 81,43 $\%$, untuk kategori baik (B) sebesar 14,86 \% dan untuk kategori lain masing-masing $0 \%$. Total skor yang dicapai adalah 337 dengan skor maksimum 350 dan persentase yang dihasilkan adalah $96,3 \%$.

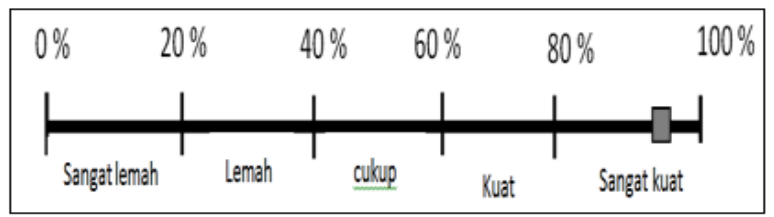

Gambar 5. Skala penilaian kontinum respon siswa terhadap bahan ajar berbasis multimedia

Berdasarkan skala penilaian didapati bahwa siswa memberikan respon positif "sangat kuat" terhadap bahan ajar berbasis software multimedia yang diberikan dan tidak terdapat perubahan item untuk direvisi pada revisi tahap 2 maka uji coba dapat dilanjutkan ke tahap uji coba lapangan (real class).

\section{Ujicoba Lapangan (Real Class)}

Bahan ajar Fisika berbasis software multimedia ini diujicobakan pada 28 orang siswa kelas X IPA 5 SMA Negeri 1 Tondano pada bulan September tahun 2019 selama 1 bulan dengan 3 kali pertemuan. Masing-masing siswa diberikan softcopy bahan ajar sesuai dengan kelompok dan masing-masing kelompok menyiapkan laptop minimal 1 buah tiap kelompok. Untuk situasi tertentu digunakan LCD proyektor dalam pembelajaran. Sebelum dilanjutkan dengan proses pembelajaran, siswa dimintakan untuk mengisi angket respon terhadap bahan ajar berbasis software multimedia. Hal ini bertujuan untuk mengetahui presentase respon siswa pada real class terhadap bahan ajar yang disediakan.

Hasil rekapitulasi pengujian angket responden siswa mencapai jumlah 1326 dengan skor maksimum 1400 mendapatkan nilai presentase $94,7 \%$ didapat dari pembagian jumlah skor yang diperoleh dengan jumlah skor maksimum dikalikan $100 \%$. Hasil respon siswa terhadap bahan ajar berbasis Autoplay media studio tergolong pada kategori sangat baik. Selanjutnya dilakukan uji empiris untuk menguji hipotesis penelitian yang menggunakan nilai hasil belajar siswa pada periode 1 dan periode 2. Hasil belajar siswa diperoleh melalui tes hasil belajar dengan instrument yang telah diuji validitas dan reliabilitas butir soal dengan $\alpha=$ 0,05 kriteria pengujian sebagai berikut: Jika $t_{\text {thitung }}>t_{\text {tabel }}$ berarti valid, atau Jika thitung $\leq t_{\text {tabel }}$ berarti tidak valid. Perhitungan validitas dan reliabilitas dilakukan dengan bantuan SPSS v.16.

Pengujian validitas butir soal hasil belajar siswa disusun 27 butir dengan 28 responden. Untuk $n=28, r_{\text {tabel }} 0.374$ setelah diuji validitas terdapat 25 butir soal valid dan 2 butir soal tidak valid. Dengan demikian 25 butir soal tersebut dapat digunakan untuk mengukur hasil belajar siswa. Selanjutnya dihitung koefisien reliabilitas dengan menggunakan persamaan Kuder Richardson: (KR-20) diperoleh hasil 0.89 yang menunjukkan bahwa data tersebut adalah reliabel dan digunakan berulang kali tetap konsisten.

\section{Prosedur Pembelajaran}

Dalam pembelajaran menggunakan bahan ajar fisika berbasis software Autoplay media studio perlu dianalisis kinerja siswa saat proses pembelajaran dengan berlangsung. Proses pembelajaran dilakukan sebanyak 3 kali pertemuan dan setiap pertemuan dibagi dalam 4 kelompok besar yang terdiri atas 7 orang siswa per kelompok. Analisis kinerja dilakukan 
secara pribadi bergantung pada aktivitas siswa dalam kelompok masing-masing.

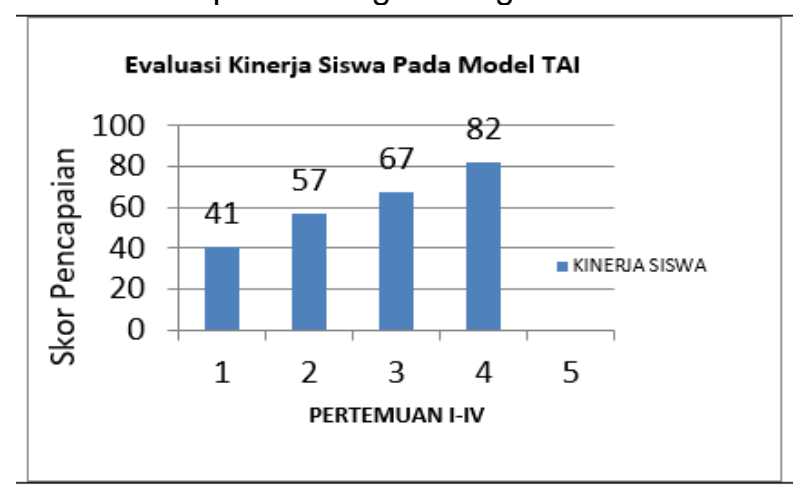

Gambar 6. Evaluasi Kinerja Siswa

Kinerja siswa pada pertemuan pertama nampak masih kurang dengan skor rata-rata 41 oleh sebab fase adaptasi siswa dengan model pembelajaran yang baru diterapkan dengan menggunakan bahan ajar fisika berbasis Autoplay media studio namun demikian pada pertemuan selanjutnya terlihat siswa mulai beradaptasi dengan model pembelajaran dengan media yang digunakan. Skor rata-rata kinerja siswa pada pertemuan kedua mencapai 57, pertemuan ketiga 67 dan pertemuan keempat 82. Hal ini membuktikan bahwa dalam setiap pertemuan terdapat peningkatan kinerja siswa secara signifikan. Model pembelajaran berbasis Autoplay media studio (periode 2) mengajarkan siswa untuk saling berinteraksi dalam kelompok dimana mereka akan bekerja sama memecahkan masalah atau mempelajari materi yang diberikan melalui bahan ajar suhu dan kalor berbasis Autoplay media studio.

Tahap keempat yaitu tahap disseminate (Penyebaran). Pada tahap ini jika produk yang dihasilkan disetujui dan sesuai dengan analisis eksperiment yang dilakukan pada tahap ujicoba lapangan maka dinyatakan layak untuk digunakan dan disebarkan.

Untuk menguji hipotesis penelitian digunakan statistik design by subject uji paired-samples Ttes. Sebagai kriteria pengujian hipotesis : tolak $\mathrm{H}_{0}$ jika $t>t_{\alpha}$ dengan $\alpha=0.05$.

Ho $=\mu_{1} \leq \mu_{\mathbf{2}}$ : "Rata-Rata hasil belajar siswa yang diajar menggunakan bahan ajar berbasis Autoplay media studio lebih rendah atau sama dengan hasil belajar siswa yang diajar dengan menggunakan model konvensional".

$\mathbf{H}_{\mathbf{1}}=\boldsymbol{\mu}_{\mathbf{1}}>\boldsymbol{\mu}_{\mathbf{2}}$ : "Rata-rata hasil belajar siswa yang diajar menggunakan bahan ajar berbasis Autoplay media studio lebih tinggi daripada hasil belajar siswa yang diajar dengan model kovensional".

\section{HASIL DAN PEMBAHASAN \\ Deskripsi Hasil Belajar Siswa}

Berdasarkan desain by subject yang digunakan dalam penelitian ini data hasil belajar terdiri atas dua periode yaitu periode 1 yang diajar dengan model konvensional dengan media yang biasa digunakan dan periode 2 yang diajar dengan menggunakan bahan ajar berbasis Autoplay media studio yang dihasilkan.

Tabel 5. Statistik Hasil Belajar siswa periode 1 dan periode 2

\begin{tabular}{ccc}
\hline & Periode 1 & Periode 2 \\
\hline $\mathrm{N}$ & 28 & 28 \\
\hline Total & 66.80 & 87.20 \\
\hline skor Min & 1.80 & 2.60 \\
\hline skor Maks & 3.20 & 3.80 \\
\hline STDV & 0.37 & 0.31 \\
\hline Mean & 2.39 & 3.11 \\
\hline Median & 2.40 & 3.20 \\
\hline Modus & 2.40 & 3.20 \\
\hline Rentang & 1.40 & 1.20 \\
\hline
\end{tabular}

Sumber: Data dioleh di microsoft excel

Dari hasil pengujian pada periode 1 didapatkan 5 siswa memperoleh tuntas dengan predikat B dan 23 siswa tidak tuntas dengan predikat C. Skor maksimum yang dapat dicapai dengan model konvensional 3.20 dan skor minimum 1.80 dengan total skor 66.80. Skor maksimum yang dapat dicapai dengan menggunakan bahan ajar berbasis Autoplay media studio adalah 3.80 dan skor minimum 2.60 dengan total skor 87.20 .

Uji Prasyarat Analisis Data (uji normalitas) Uji normalitas hasil belajar fisika siswa dilakukan terhadap dua data yaitu pada periode 1 dan periode 2. Pengujian normalitas menggunakan uji Shapiro-Wilk dengan kriteria : Jika nilai (sig.) signifikan $>0,05$ maka data berdistribusi normal namun jika nilai signifikan $<0,05$ maka data tidak berdistribusi normal. Taraf nyata $\alpha=0,05$ dan $n=28$. Pengujian ini dibantu dengan SPSS v.16 dengan hasil sebagai berikut.

Tabel 6. Uji Normalitas Data Periode 1 dan 2

\begin{tabular}{|c|c|c|c|c|}
\hline \multirow{2}{*}{$\begin{array}{c}\text { Perio } \\
\text { de }\end{array}$} & \multicolumn{2}{|l|}{$\begin{array}{l}\text { Kolmogorov- } \\
\text { Smirnov }^{\mathrm{a}}\end{array}$} & \multicolumn{2}{|l|}{ Shapiro-Wilk } \\
\hline & $\begin{array}{l}\text { Stati df } \\
\text { stic }\end{array}$ & Sig. & $\begin{array}{l}\text { Statist df } \\
\text { ic }\end{array}$ & Sig. \\
\hline $\begin{array}{l}\text { Perio } \\
\text { de } 1\end{array}$ & .128 & $.200^{*}$ & .957 & .297 \\
\hline $\begin{array}{l}\text { Perio } \\
\text { de } 2\end{array}$ & .145 & .139 & .954 & .256 \\
\hline \multicolumn{5}{|c|}{ a. Lilliefors Significance Correction } \\
\hline \multicolumn{5}{|c|}{ This is a lower bound of the true significance } \\
\hline
\end{tabular}

Nilai signifikan pada periode 1 diperoleh 0.297 
dan periode 2 diperoleh 0.256 yang nilainya lebih besar dari 0.05 maka disimpulkan kedua data pada periode 1 dan periode 2 berdistribusi normal.

\section{Uji Hipotesis}

Pengujian hipotesis menggunakan uji paired-samples $t$-tes merupakan "analisis dengan melibatkan dua pengukuran pada subjek yang sama terhadap suatu pengaruh atau perlakukan tertentu" (Sudjana, 2005) seperti halnya dalam kasus penelitian ini. Pengujian bertujuan untuk menguji perbedaan rata-rata antara dua sampel yang berpasangan. Hasil pengujian hipotesis (SPSS v. 16) sebagai berikut.

Tabel 7. Hasil Analisis Paired-samples T-test

\begin{tabular}{|c|c|c|c|c|c|}
\hline \multicolumn{6}{|c|}{ Paired Samples Statistics } \\
\hline & & Mean & $\mathrm{N}$ & $\begin{array}{c}\text { Std. } \\
\text { Deviation }\end{array}$ & $\begin{array}{l}\text { Std. Error } \\
\text { Mean }\end{array}$ \\
\hline \multirow[t]{2}{*}{ Pair 1} & Periode1 & 2.3857 & 28 & .37289 & .07047 \\
\hline & Periode2 & 3.1143 & 28 & .30998 & .05858 \\
\hline \multicolumn{6}{|c|}{ Paired Samples Correlations } \\
\hline & & $\mathrm{N}$ & & Correlation & Sig. \\
\hline Pair 1 & $\begin{array}{l}\text { Periode1 } \\
\text { Periode2 }\end{array}$ & $\&$ & 28 & .848 & .000 \\
\hline
\end{tabular}

Paired Samples Test

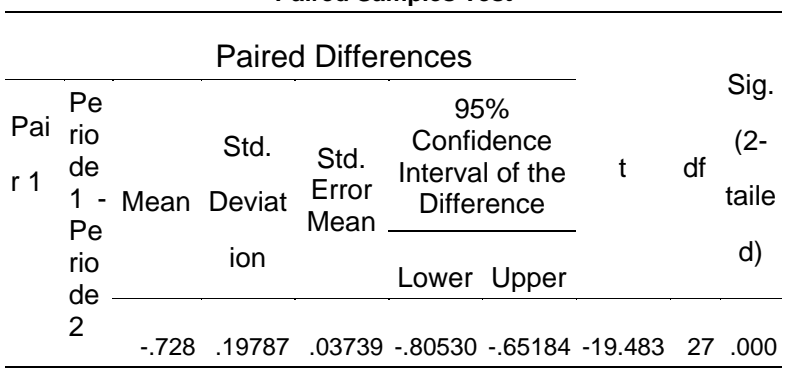

\section{Interpretasi output SPSS}

Tabel 4 bagian paired samples statistic menyajikan deskripsi data dari pasangan variabel yang dianalisis meliputi rata-rata (mean) periode 1 yaitu 2.38 dengan standar deviasi 0.37 dan periode 2 rata-rata (mean) yaitu 3.11 dengan standar deviasi 0.309. Tabel 4 bagian kedua paired samples correlations diperoleh hasil korelasi kedua variabel dengan angka 0.848 probabilitas (sig.) 0.000 dapat disimpulkan bahwa hasil belajar siswa yang diajar dengan model konvensional (periode 1) dan hasil belajar siswa yang diajar dengan menggunakan bahan ajar berbasis Autoplay media studio (periode 2) berhubungan secara nyata, sebab nilai probabilitasnya $<0.05$ dan nilai korelasi mendekati 1 . Tabel 4 bagian ketiga paired samples t-test diperoleh hasil pengujian hipotesis dengan dasar
Pengambilan keputusan dengan uji paired samples $t$-test sebagai berikut :

Berdasarkan kriteria pengujian :

Jika $\left|t_{\text {hitung }} \leq \mathrm{t}_{\text {tabel }}\right|$ maka $\mathrm{H}_{0}$ diterima

Jika $\left|\mathrm{t}_{\text {hitung }}>\mathrm{t}_{\text {tabel }}\right|$ maka $\mathrm{H}_{0}$ ditolak

Berdasarkan signifikansi :

Jika signifikansi $>t_{\alpha} \quad(\alpha=0.05)$ maka $\mathrm{H}_{0}$ diterima

Jika signifikansi $<t_{\alpha} \quad(\alpha=0.05)$ maka $\mathrm{H}_{0}$ ditolak.

Hasil analisis, thitung $=-19.483$ sedangkan statistik tabel dengan tingkat signifikansi (a) $5 \%$ tabel $=-2.473$ Selanjutnya membuat kesimpulan berdasarkan kriteria pengujian. Karena nilai $\left|\mathrm{t}_{\text {hitung }}>\mathrm{t}_{\text {tabel }}\right|$ atau $|19.483>2.473|$ maka $H_{0}$ ditolak dan berdasarkan signifikansi $<0.05$ maka $\mathrm{H}_{0}$ ditolak. Disimpulkan bahwa Rata-rata hasil belajar siswa yang diajar menggunakan bahan ajar berbasis Autoplay media studio lebih tinggi daripada hasil belajar siswa yang diajar dengan model kovensional.

Materi suhu dan kalor termasuk materi yang menyajikan konsep fisika secara abstrak seperti konsep perpindahan kalor secara konduksi, konveksi dan radiasi serta pengukuran suhu menggunakan skala celcius, fareheit, reamur dan kelvin yang apabila disajikan dengan multimedia Autoplay media studio yang didukung simulasi audio visual akan lebih memudahkan guru dalam penyampaian konsep-konsep fisika serta memudahkan siswa dalam pemahaman materi yang diajarakan oleh guru. Menurut hasil penelitian dari (Bahri,2018) "Belajar dengan menggunakan Autoplay media studio 8 memudahkan siswa dalam mengingat pesan yang disampaikan sebab terstrukturnya dan terekam sesuai keadaan saat recording". Penelitian lainnya menyatakan kepraktisan guru menggunakan media pembelajaran Autoplay media studio sangat baik dengan presentase sebesar $93,12 \%$ dan hasil belajar siswa dinyatakan baik sebesar $84 \%$ ketuntasan belajar. (Setiawan, 2017) serta penelitian dari (Kuron, M. A., \& Tompodung, M., 2020) tentang pengembangan bahan ajar multimedia offline pada materi IPA Terpadu Kelas VIII SMP Negeri 2 Ranoyapo menunjukkan peningkatan prestasi siswa dengan penggunaan bahan ajar berbasis multimedia

Bahan ajar fisika materi suhu dan kalor ini dirancang secara terstruktur dan menarik serta disesuaikan dengan kondisi peserta didik sehingga pada saat digunakan dalam pembelajaran dapat menghasilkan proses yang 
efektif dan efisien serta lebih maksimal dalam penggunaan waktu belajar. Bahan ajar fisika suhu dan kalor ini juga dapat dipadukan dengan penggunaan model pembelajaran yang efektif sesuai dengan keberadaan siswa di masingmasing sekolah. Penggunaan Autoplay media studio ini dapat menjadi salah satu solusi dalam mengatasi kesulitan-kesulitan yang dijumpai saat pembelajaran berlangsung serta cara-cara penyelesaian soal sehingga dapat mempermudah proses pembelajaran dalam mencapai tujuan.

\section{SIMPULAN DAN SARAN}

Simpulan dari penelitian ini diantaranya 1) Produk bahan ajar fisika berbasis Autoplay media studio yang telah dikembangkan dan dihasilkan melalui penelitian ini layak digunakan untuk memperbaiki proses pembelajaran dimana respon ahli materi menunjukkan persentasi $88 \%$ respon ahli media menunjukkan persentasi $65 \%$ pada tahap pertama dan persentase $97 \%$ revisi, serta respon siswa pada uji kelompok kecil menunjukkan persentasi 96,3\% dimana semua tahap pengujian berada pada kategori sangat kuat, 2) Pengunaan bahan ajar berbasis Autoplay media studio dapat meningkatkan hasil belajar siswa pada materi suhu dan kalor dimana hasil pengujian menunjukkan hasil belajar siswa diperoleh thitung sebesar 19,483 dan $t_{\text {tabel }}$ sebesar 2,473 yang berarti $t_{\text {hitung }}>t_{\text {tabel }}$ disimpulkan bahwa rata-rata hasil belajar siswa yang diajar menggunakan bahan ajar berbasis Autoplay media studio lebih tinggi daripada hasil belajar siswa yang diajar dengan model kovensional, 3) Bahan ajar fisika berbasis Autoplay media studio dapat membantu siswa mempermudah pemahaman materi, membantu guru dari segi efisiensi waktu, membuat proses belajar yang kreatif dan membantu siswa dalam pembelajaran mandiri.

Saran dari penulis diantaranya 1) Baik menggunakan produk bahan ajar fisika berbasis Autoplay media studio pada proses pembelajaran di sekolah lebih khusus kelas $X$ SMA dengan materi suhu dan kalor bagi guru maupun siswa, 2) Bahan ajar fisika berbasis Autoplay media studio dapat dikembangkan untuk materi fisika yang lain agar memperoleh bahan ajar yang lengkap.

\section{UCAPAN TERIMAKASIH}

\begin{tabular}{lrr}
\multicolumn{2}{c}{ Terima kasih kepada } & Lembaga \\
Penelitian dan Pengabdian & Kepada \\
Masyarakat Universitas Sariputra & Indonesia \\
Tomohon (UNSRIT), Fakultas & Teknik, \\
Lembaga Penelitian Jurnal Kajian, Inovasi dan \\
Aplikasi pendidikan Fisika (ORBITA) Fakultas \\
Keguruan dan IImu Pendidikan Universitas
\end{tabular}
Muhammadiyah Mataram, disampaikan juga terima kasih kepada LLDIKTI Wilayah XI dan kepada semua pihak yang telah mendukung dan memotivasi peneliti selama melaksanakan penelitian ini.

\section{DAFTAR RUJUKAN}

Ariani, N., \& Haryanto, D. (2010). Pembelajaran Multimedia di Sekolah. Jakarta: Prestasi Pustaka.

Arikunto, S. (2010). Prosedur Penelitian Suatu Pendekatan Praktik. Jakarta: Rineka Cipta.

Arsyad, A. (2012). Media Pembelajaran: Bandung. Rosdakarya.

Bahri, Arsad. (2018). Penggunaan Media Berbasis Autoplay Media Studio 8 untuk meningkatkan aktivitas dan hasil belajar siswa. Proceeding Biology Education Conference Vol. 15, No(1) hal. 394-402 p-ISSN:2528-5742.

Daryanto. (2010). Media Pembelajaran. Yogyakarta: Gava Media.

Fitria, H. (2013). Pengembangan Strategi Problem Based Learning Pada Mata Kuliah Strategi Belajar Mengajar Jurnal Dosen Universitas PGRI Palembang. URL:

https://jurnal.univpgripalembang.ac.id/i ndex.php/prosiding/articl e/view/1558/1363.

Haryanto, D. (2010). Pembelajaran Multimedia. Jakarta: Prestasi Pustaka.

Kuron, M., A., \& Tompodung, M. (2020). Pengembangan bahan ajar multimedia offline pada materi IPA Terpadu Kelas VIII SMP Negeri 2 Ranoyapo. Jurnal Pendidikan Informatika dan Sains, 9 (2), 121-131.

https://journal.ikippgriptk.ac.id/index.ph p/saintek/article/view/1760]

Pressman, R.,S. (1997)., Prasetyo. (2012)., dalam Palilingan, R. (2014). Bentuk Langkah-Langkah Metode R\&D. "Software Engineering: A Practioner's Approach." 4th. McGraw Hill Jurnal Pendidikan Program S2 Pendidikan IPA Pascasarjana UNIMA.

Putra, N. (2015). Research \& Development Penelitian dan Pengembangan. Jakarta: PT Raja Grafindo Persada.

Setiawan, Agus. 2017. Pengembangan Media Pembelajaran Menggunakan Software Autoplay Media Studio 8 Pada Mata Pelajaran Perekayasaan Sistem Radio dan Televisi kelas XI SMK Negeri 1 Sidoarjo. Jurnal Pendidikan Teknik Elektro. Vol. 06. No. 01 hal. 85-91. 
Setyosari, P. (2010). Metode Penelitian Penelitian dan Pengembangan. Jakarta: Kencana

Sudjana. (2005). Metode Statistika. Bandung: Tarsito. 